K US TA A VIL KUNA

\title{
Talviapajan avaaminen Rymättylän vesillä
}

Nykyisin (1962) Rymättylässä on 12 perinnäistä nuottuuta, jotka säännöllisesti vetävät airisto- eli talvinuottaa - edellinen nimitys, joka viittaa mahdollisesti talvinuotan vanhimpaan käyttöalueeseen, on jo unohtumassa. Viime vuosisadan lopulla nuottakuntia oli ainakin kahdeksan, mutta aikaisemmin vuosisadan puolivälissä nuottia perimätiedon mukaan oli vakinaisesti vain kolme neljä. Vakinaisimmat olivat Jäntti, josta käytettiin myös nimeä Jäntinuotta, Kurinen eli Kuristen nuotta ja Luoto (Luodon nuotta) ${ }^{1}$. Näistä Kurinen ja Luoto olivat ilmeisesti saaneet nimensä vanhojen pääosakkaiden osamiesten - asuinpaikan mukaan: Kuristenkylä pitkän Kuristensalmen - nyt pitkä ja kapea lahti eli peräksin - pohjoisrannalla ja (Aasla-) Luoto Omenaisten aukon ja Airistmaan välissä. Vielä uudenajan alussa Aasla oli myös Rymättylän eteläisen verokunnan nimi ("Assla Bool")2 . Varsin mielenkiintoista on panna mer-

1 P. A. Nummelin, Talvinuottakalastus Rymättylän tienoilla (1908). Kopiv Suomalaisen Kirjallisuuden Seuran arkistossa, s. 2 ja 7 . Alkuperäinen käsikirjoitus Turun Maakunta-arkistossa Nummelinin kokoelmassa. Luonnonmaan Käkölän isännän Petrus Augustinus Nummelinin (1835-1925) omat talvikalastusmuistot ulottuvat 1840-luvulle, jolloin hän jo oli mukana seuraamassa nuotanvetoa. Tämän kirjoitelman tärkeimpänä lähteenä on sanottu käsikirjoitus ja maisteri Väinö Talan vuosina 1945-1947 keräämä Rymättylän sanasto sekä omat muistiinpanoni vuosilta 1938, 1945, 1950 ja 1962. Parhaimpina tietomestareina kirjoittajalla ovat olleet Terho Koisaari (s. 1889), Janne Koivuniemi (s. 1888), Vieno J. Kustonen (1892-1957) ja Eero Kustonen (s. 1919).

${ }^{2}$ Warsinais-Suomen maakirja w:lta 1540. Hki 1930, s. 124. Aaslan verokuntaan kuuluivat v. 1540 Aaslaluodon kylät Ali-, Vanlı- ja Ylikylä sekä Hanka, Pulkkala ja Meinikkala (Menickala); nykyisen mantereen eteläosasta siihen kuuluivat Ahteentaka (Actantaka), Kepuinen, Kinttala, Kirjala, Montola, Okala ja Vuorenpää (Vorenpä) sekä "Ledelaks". 
kille, että mainitut kolme vakinaista nuottaa tavataan helposti tunnettavilla nimillä v. 1560 laaditussa 'linnan silakkaa" (Slott Strömming') maksavien nuottakuntien veroluettelossa: Kuris, Assla ja Jensi ${ }^{3}$. Viimeksi mainittu on luettava Jänsi ja sellaisena se edustaa Jänttinimen alkuperäistä nominatiivia. Uusi perusmuoto on ehkä saatu taivutussijoista: gen. jännen, part. jänttä, vrt. onsi, part. ontta, toinen perusmuoto ontto. Uusi perusmuoto oli käytössä jo 1700-luvun alussa. Jäntin talvinuottakunta (Jänti nootlag) tuli näet 1726 esille Rymättylän käräjillä, jolloin sanottu nimimuoto menkittiin pöytäkirjaan. - Talvinuotan niminä nämä ovat yhä muistissa, mikä oikeuttaa väittämään, että ne olivat talvinuottia myös 400 vuotta sitten. Samassa luettelossa mainitaan saman suuruisen kalaveron maksajina lisäksi viisi muuta nuottaa: Mampä (Maanpää, kylä Airismaalla), Rockrauma (Ruokorauma, kylä itärannalla), Kurirauma (Kurjenrauma, kylä länsirannalla), Pakinnais (Pakinainen, saari Länsiaukossa, kylä ja vanha verokunta kuten Aaslakin, 1540 Pakina Bool) ja Grijmi. Ilmeisesti nämä kaikki ovat talvinuottakuntia. Esim. Maanpään tilasta, joka 1460 liitettiin Turun Tuomiokirkon omistuksiin, tiedämme, että se 1658 omisti kahdeksannen osan talvinuotan perästä ja 1732 koko perän; Ruokorauman talvinuotta (Ruokorauma noot) mainitaan Rymättylän käräjillä 1726, ja uudelleen syntyneenä se mainitaan 1880-Iuvulla, myöhemmin siitä käytettiin nimeä Pohjakulman nuotta. Myös Pakinaisten nuotta oli jääpyynnissä 1880luvulla. Edelleen vuodelta 1737 on tieto, että "Grimmin" talvinuotta yhtyi Kuristen nuottaan *; ilmeisesti "Grimmi" ja v. 1560 mainittu

${ }^{3}$ Peder Brunttesons opbörd och uttgift af Korpo, Töfsala och Kimitto socknar; alussa Register på notfisk. Valtionarkisto 864, f. 2.

4 "Grimmi" ja "Jänsi" talvinuottien niminä eivät viittaa omistajiin, vaan ovat saaneet nimensä teknillisestä uutuudesta tai muusta seikasta. Grimmi-nimi on ilmeisesti annettu tälle Rymättylän talvinuotalle siksi, että siinä ehkä ensim. mäisenä otettiin käytäntöön kriimut (ruots. grimma, -or, muin. ruots. grĩma, murt. grimo), jotka yhdistävät taukoköyden pauloihin. Vanhempi ja, talvinuotassa vähemmän tehokas menetelmä on säilynyt suvinuotissa, joissa tauko on kiinnitetty suoraan keskelle koiriopuuta. Riimuja käyttäen saatiin koirioverkot korkeammiksi ja joustavammin toimiviksi. Ahvenanmaalta Saltvikin Hagan kuninkaankartanosta riimunuotta mainitaan 1558 (K. R. Melander, Sillin eli suurhailin kalastuksesta maassamme 1500-luvulta alkaen, s. 311. Hist. tutkimuksia XII, 1931) ja Turussa "grimme-Noot" mainitaan Hans Magenin peruissa 1636 (Bidrag till Åbo stads historia I: 8, s. 217. Hki 1896). Eräästä käräjäpöytäkirjasta v:lta $1627 \mathrm{käy}$ ilmi, että Rymättylän Grimmi-nuotan pääomistaja oli Ravolax eli nykyinen Raulan kylä (Melander, mt. s. 310). 
"Grijmi" "tarkoittavat samaa talvinuottaa ${ }^{5}$. On siis mitä todennäköisintä, että kaikki v. 1560 laaditussa luettelossa mainitut nuotat tarkoittavat talvinuottia. Tällainen pyyntivälineiden ja nuottakuntien viuosisatainen vakiintuneisuus kertoo Rymättylän seudun talvinuottakalastuksen pitkästä iästä ja perinteen vahvuudesta.

Eniten vastuuta ja paikallistietoa suurisuuntaisessa silakan talvikalastuksessa Turunmaan saaristossa vaatii yhä edelleen kunkin nuotta-apajan, luoman, ensimmäinen avaaminen syystalvella. Seuraavat vetokerrat ovat helpot suorittaa, koska ensimmäisen nuottuuden sytemät avannot tai niiden merkit ovat nähtävissä läpi talven jäänlähtöön saakka. Sen sijaan ensimmäisellä kerralla pelkkä sileä jää peittää meren pinnan, jonka alta on löydettävä niin laaja-alainen ja sopivan syvä pohjatasanko, että sille voi vetoa varten laskea jättiläismäisen talvinuotan.

P. A. Nummelinin yksityiskohtaisen esityksen mukaan "airistnuatta" oli koottu 84 verkosta, jolloin verkkoa oli yhteensä 2070 kyynärää (1229 m). Kunkin verkon leveys oli 200 silmää tiheydestä riippumatta. Pauloitettuna sellaisen nuotan pituus lähenteli paria sataa metriä, saattoi olla ylikin. Monen talon kotoisena työnä hampusta nuotaksi se maksoi melkoisen omaisuuden. Pyydystä liikuttelemassa oli vähintään 24 miestä ja 7 hevosta. Ennen hevoskiertoisten tynnyreiden käytäntöön tuloa 1870-luvulla tarvittiin nuottaa pihdeillä tai kluvilla vetämään $48-60$ henkeä ${ }^{6}$. Jos nuotta olisi tarttunut kiinni, olisi kallis pyydys siitä kärsinyt jaiainakin päivän ja kahdenkin vaivat olisivat väkijoukolta menneet hukkaan. Siksi oli löydettävä pohjasta aluie, jossa oli puhdas vesi, jossa ei siis ollut kiintimiä ${ }^{7}$. Ne oli todella ennakolta tiedettävä, sillä Turunmaan saaristomeren pohja on oilkulilista. Siellä on tiheässä kiintiminä kivisiä riuttoja, syviä juopia, yksinäisiä kiviä, ooseja ja äkkinäisiä prantteja ${ }^{8}$, joiden taakse nuotan raskaasti kivitetty alipaula puuttuu lähtemättömiin. Jos näin käy, alkaa vaivalloinen kiintimien etsiminen ja nuotan nostaminen etsintäavannoista. Tällainen tapaus on myös suureksi

5 Varsinais-Suomen historia II : 2, s. 178, 181-2, 247.

- Mainittu kopio, s. 47.

${ }^{7}$ Murteessa kiinttin, gen. kiinttimen. Pienemmistä kiintimistä on käytetty myös nimiä kcarhunkäpälä ja kissankynsi.

${ }^{8}$ Ruotsin ass 'harjanne', brant 'jyrkänne, rinne'. 
häpeäksi työn johtajalle eli pomolle, jota vielä ennen ensimmäistä maailmansotạa sanottiin yksinomaan nuotankuninkaaksi, usein vieläkin. Hänelle on näet aina yksin kuulunut koko vastuu nuottaluoman avaamisesta, paikan yksityiskohtaisesta määrittelemisestä. Hänen oli tunnettava tamholtit $^{9}$ eli maamerkeistä laskettavat suunnat.

Tiedot tunnetun luoman tarkasta sijainnista ovat kulkeneet perintönä kuninkaalta toiselle. Ensimmäisenä perustana kuninkaan on tiedettävä maamerkeistä saattimen paikka, takamerkki ja kor(v)onmerkki.

Saatin eli nostoavanto sijaitsee lähellä rantaa paikalla, jossa on vielä vettä ainakin puolitoista syltä eli lähes kolme metriä. Rannassa on jokin erityinen kivi, puu, kallion kieleke, vuorten leikkaus tai muu mieleen jäänyt paikallispiirre, josta paikka on tunnettavissa. Myös veden syvyys on tiedossa, joten kuningas ottaa vain tietyn luvun askelia rannasta kohti aukkoa ja laskee jäälle saatinhaon saattimen merkiksi. Tästä hän ottaa edellensä nuottamiehen tai parikin ja asettuu heidän kanssaan jonoon siten, että hän saattaa näiden yli nähdä takamerkin, joka on jokin kallio, niemenkärki, puu tai rakennus ulompana, kaukanakin. Tämä on luoman pituussuunta. Miehet lähtevät käymään suoraa linjaa kohti takamerkkiä. Viimei-

9 Ruotsin stamhâll, tanskan stamhol; sana tavataan Rymättylän ruotsinkielisillä naapureilla: stamhåll 'kursmärke akteröver vid rodd' (Kumlinge), 'siktmärke akteröver vid rodd' (Kökar), 'kursmärke vid vandring i skog' (Parainen), 'landmärke akteröver' för kurstagning vid rodd' (Hiittinen), Svenska Litteratursällskapet i Finland -arkiston kokoelmat. Länsi-Uudeltamaalta $H$. Vendell on maininnut myös muodon stamm-håld 'stamhâll vid rodd' (Samlingar af ord ur nyländska allmogemålet, 1884, s. 224). Jos sana olisi laina Turunmaan ruotsalaisilta, odottaisi suomessa muotoa ${ }^{*}$ tamhalti. Kyseessä lainanantajana voi olla keskiajan alasaksan värittämä merimieskieli, keskialasaksassa ja myöhemmässä alasaksassa ruotsin håll, håld (< hald-) sanaa vastaava sana äännettiin holt, joka on suomeen antanut holtti-sanan (T. E. Karsten, Finnar ocl germaner, 126, Folkmålsstudier IX, 1943) ; keskialasaksan holt merkitsi nimenomaan 'Richtung, Kurs (von Schiffen)' (August Lübben, Mittelniederdeutsches Handwörterbuch, 1888, s. v. holt). Myös hollannin merikielessä tavataan Stamhaltt keulamerkin nimenä (A. Stjerncreutz, Suomalainen Meri-sanakirja, Hki 1863, s. 346). Stamhåll-sanan synty liittyy kesäiseen vesillä soutamiseen. Lähtiessään rannasta soutaja, joka istuu takaperin menosuuntaan, ottaa maamerkin, johon liän tälitää perävantaan (stam) yli pitäen silmänsä vantaan nokan ja maamerkin kanssa samassa linjassa eli suunnassa (hall, holt), jolloin vene etenee suoraan päämääräänsä. 
senä kävelevä kuningas tarkkailee, että he pysyvät siinä tamholtissa, jonka toisessa päässä on saatin, toisessa takamerkki. Jos edessä apajan suunnassa ei ole sopivara takamerkkiä, voidaan se ottaa takaakin, siis saattimen maan puoleisista mahdollisista maamerkeistä, jolloin ainakin ensimmäisen on takaperin kulkien tarkkailtava linjassa pysymistä. Kun on kärelty suunnilleen luoman korko eli pituus (korkeus), kuningas alkaa tähyillä koronmerkkiä (murt. korvonmerkki). Sen muodostaa kaksi maastossa sivulla olevaa pistettä, kuten vuori ja niemenkärki, saaressa oleva laakso ja sen takana näkyvä kallio tms., joiden kautta kulkevalle suoralle kuningas nyt tulee. Missä nämä etsityt pisteet ja kuningas tekevät kolmea, siinä on jälleen oikea tamholtti. Missä nämä kaksi linjaa leikkaavat, "tekevät kolmea", siinä on laskimen eli sen avannon paikka, josita nuotta lasketaan jään alle. Tähän pannaan merkiksi laskinhako. Aina ehkä laskimen paikka ei satu juuri linjojen leikkauspisteeseen; silloin kuninkaan on tiedettävä, montako askelta ja mihin suuntaan leikkauspisteestä on vielä astuttava. -- Nuottakuormat kaadetaan taakse tiettyyn järjestykseen ja nuotan kokoaminen eli jamasaumojen ompelu voi alkaa. Ennen nuotan valmistumista on kuninkaan osoitertava. luoman aukko- ja maapolvet sekä rehdot ${ }^{10}$.

10 Tässä yhteydessä mainittakoon myös Turunmaan ruotsin murteiden rehtoavannou mielenkiintoinen nimitys, jonka Carl Jacob Gardberg on merkinnyt Västanfjärdin tienoilta muodossa drett, drettar (Fisket med vinternot i östra Kimito, Västanfjärd och Hitis. Budkavlen 28, 1949, s. 83). Kumlingessa vastaava sana ääntyy dräht, Särkisalossa drieht, Kemiössä aräit (Vendell 1904), mitkä jo tuovat mieleen Rymättylän relıto-sanan. Sanat on kuitenkin pidettävä erillään. C. J. Gardberg on huomauttanut, että Hiittisissä drett tarkoittaa koko apajaa, mikä merkitys on Kemiöstäkin asiakirjallisesti todettavissa v:lta 1634: på notedrätten 'på făngstplatsen' (John Gardberg, Kimito Friherreskap, Helsingfors 1935, s. 238). Nuotta-apajan merkityksessä drätt tavataan useissa keskiaikaisissa lähteissä (K. F. Söderwall, Ordb. ö. sv. medeltids-språket I. Lund 1884-1918, s. 202-3), myös Suomessa laadituissa asiakirjoissa: mm. Olavi Antinp. Menoinen (menoys) tuomittiin sakkoja maksamaan Saarioisten hallintopitäjän laamannin käräjillä 1509 luvattomasta nuotanvedosta, om not dretth (R. Hausen, Bidrag till Finlands historia I, Helsingfors 1881, s. 199). Sana on ilmeinen jolıdos draga 'vetää' verbistä ja on alkuaan tarkoittanut (nuotan) 'vetoa', sitten myös 'apajaa, jota vedetään' ja lopuksi myös 'avantoa, josta vedetään, vetoavantoa'; vastaavan kehityksen tuloksena ainakin Narvusin inkeriläisillä on talvinuotan vetoavannon nimenä veto (Lauri Hakulisen muistiinpano 196்1. SS). Miten nuotan vedosta on tultu merkitykseen rehtoavanto, josta nuot- 


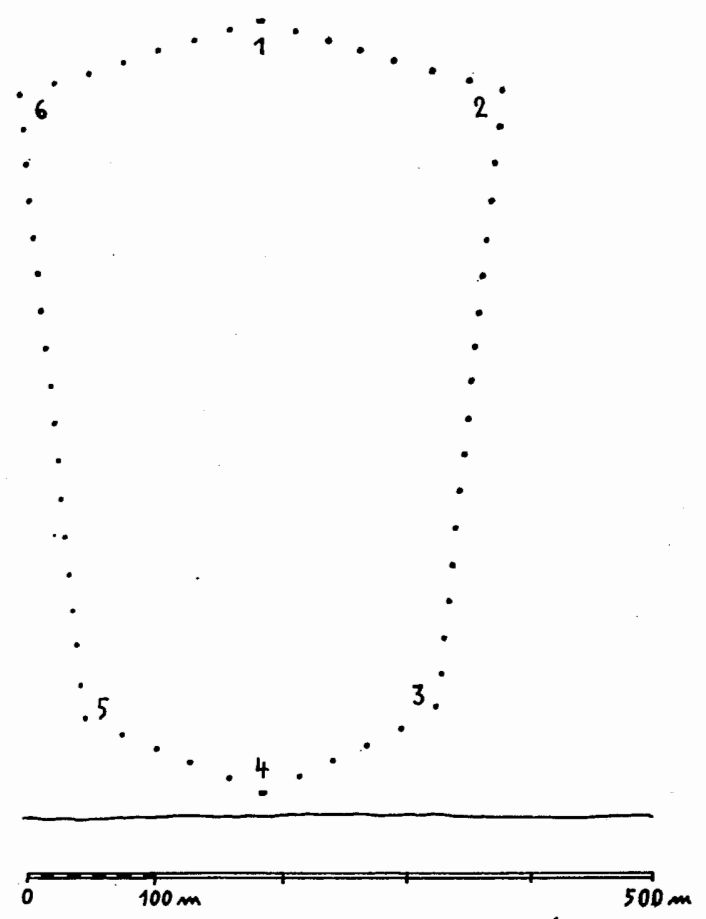

Kuva 1. Säännöllinen luoma itärannalla. 1 laskin (aukon puolella), 2 päivänpuolinen aukkopolvi, 2-3 päivänpuolinen rehto, 3 -päivänpuolinen maapolvi, 4 saatin (lähellä rantaa), 5 pohjanpuolinen maapolvi, 5-6 pohjampuolinen rehto, 6 pohjanpuolinen aukkopolvi, $6-1-2$ rinta.

Kokonaisuudessaan normaaliluoma on kahdesta vastakkaisesta kulmasta - saattimesta ja laskimesta - venytetyn kuusikulmion muotoinen (kuva 1). Muut kulmapisteet ovat aukkopolvet laskimen puolella ja maapolvet saattimen puolella. Laskimelta lähtien nuotankuningas määrää ensin aukkopolvien suunnan. Mikäli lähellä on

taa ei vedetä, vaan josta vain uittosalkoa työnnellään keksillä jään alla eteenpäin, käy ilmi Linéa Kronfeldin kuvauksesta talvinuotan vedosta Paraisilla (Fisket med vinternot i Pargas. Budkavlen 26, 1947, s. 33-47). Nuottaa vedettäessä siellä nuotan vetoköysi otettiin jäälle vain joka kolmannesta tai joka neljännestä avannosta, ja juuri näitä avantoja (vakar), joista siis köyttä vedettiin, kutsuttiin nimellä drätter (s. 40). Aikaisemmin ne elıä olivat nimeltään *drättvakar erotukseksi uittoavamoista. Kun kyseessä ovat samanlaiset avannot, niin drett-nimi saattoi yleistyä. 


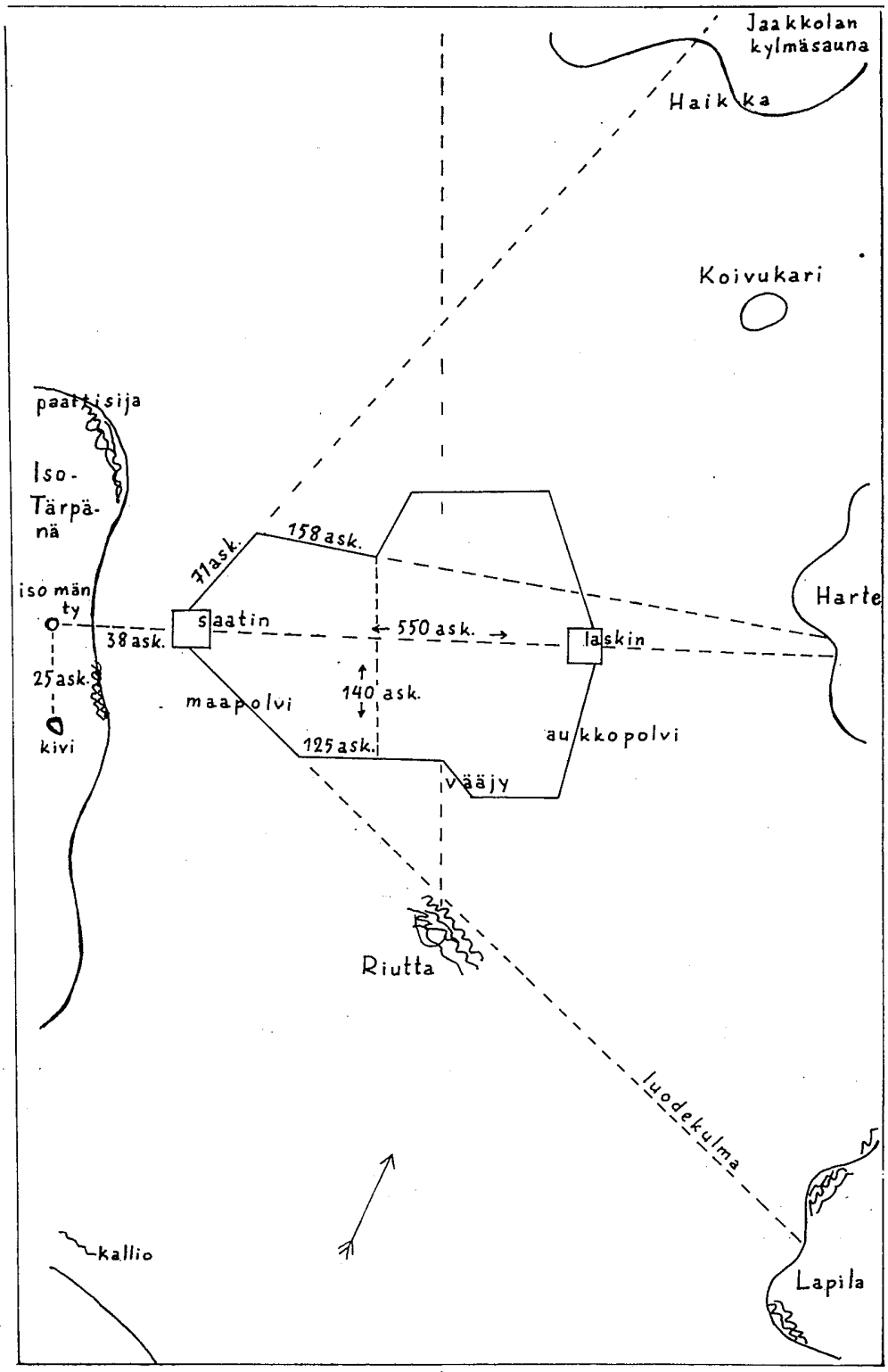

Kuva 2. Iso-Tärpänän vaikeasti avattavan luoman kartta; kuva on kirjoittajan v. 1938 hiukan täydentämä kopio Koisaaren isännän K. Th. Karlssonin (1859-1941) laatimasta piirroksesta. Lähtökohtana on Petkellahden suulla sijaitsevan Iso-Tärpänän itärannalla silmään ottava kookas kivi ja sen pohjoispuolella oleva iso mänty, jonka juurelta katsottuna takamerkki 
tunnettuja kiintimiä, on suunta ja polvien pituus tarkoin määrätty; jos pohja päin vastoin on laajalti täällä aukon puolella tasaista, nuotankuningas muodostaa polvista tylpän kulman — joskus lähes loittoon eli oikokulmaan - kärkenä laskin, jolta hän ottaa molempiin suuntiin 180_200 askelita suorassa linjassa. Näin löytyvät aukkopolvet, jotka jälleen merkitään haolla. Näin on luoman rinta selvillä. Tämän jälikeen käydään rehdot eli luoman sivurajat. Niiden pituus saattimen ja laskimen sijainnin mukaan vaihtelee puolestatoista kilometristä puoleen kilometriin; useimpien Iuomien korko jää 700-1200 metrin välille. Sivurehdot eivät ole koskaan yhdensuuntaiset, vaan luoma hiukan kapenee maalle päin. Kun kuningas ja hänen apunaan toista rehtoa käynyt osamies saapuvat sille kohdalle lähempänä rantaa, josta nuotan uitot, köydet ja reidet on käännettävä suoraan kohti saatinta, on tultu maapolville. Kulman kärki merkitään polvihaolla. Normaalitapauksissa maapolvelta on 120-150 askelta saattimelle.

Näin merkitylle luoman rajalle hakataan tuuralla tarpeelliset avannot. Hevosmiehet tekevät laskimen, kolme pitkän ja pari kyynärää leveän avannon. Työ tehdään nopeasti ja siististi, jottei jäämurskaa kentyisi nuotan tielle. Silksi hakataan vain kapea varho laskimen molempiin päihin ja sisäsivulle siis luoman puolelle, minkä jälkeen ulkosyrjä taitetaan painamalla jääkantta syrjästä. Näin syntynyt jääpaasi työnnetään jään alle luoman ulkopuolelle, jottei nuotan yläpaula tarttuisi siihen. Laskimelta alkavat läpimiehet työnsä käyden toinen kohti toista polvea, jossa merkikinä on juuri pantu hako, toinen toista. He ottavat 30 askelta, ei koskaan yli vaan mieluummin rahdun alle, sillä jään alla uitettava raaka eli uitto on tuskin 30 askelta pitempi. Laskettuaan 30 askelta läpimies pysähtyy ja laukoo rehdot, s.o. hakkaa tuurallaan jäähän kohtalaisen ämpärin suuruiset lävet. Perässä kulkeva kohvapoika nostaa siitä lapiollaan sohjon ja kaleet jäälle niin, että selvä vesi näkyy avannon pohjalta. Aukkopolville tulee 6-7 läpeä. Samanaikaisesti polviläpien kanssa

on Iso-Harteen luodolla kahden paljaan kallion välissä näkyvä pensas- ja leppäryhmä. Tässä suunnassa saattimen ja laskimen paiklka määrätään askelmitoilla. Aukkopolvien sijainti on normaali ja vapaa, sen sijaan maapolvien tamloltit on tarkoin määrätty: päivänpuolinen käy näkyvän iiutan vieritse Lapilan luodekulmaan ja pohjoisen puolinen Luonnonmaan tietyn haikan (matalan niemen) sivuitse näkyvään Jaakkolan vanhaan saunaan. Kummallakin rehdolla on tehtävä vääjyy askelmittojen ja maamerkkien mukaan. - Petkellahdessa, Luonnonmaan ja Rymättylän välissä on useita vanhoja luomia, jotka aikaisemmin olivat eniten käytettyjä. 


\section{Maskinnanmaa}

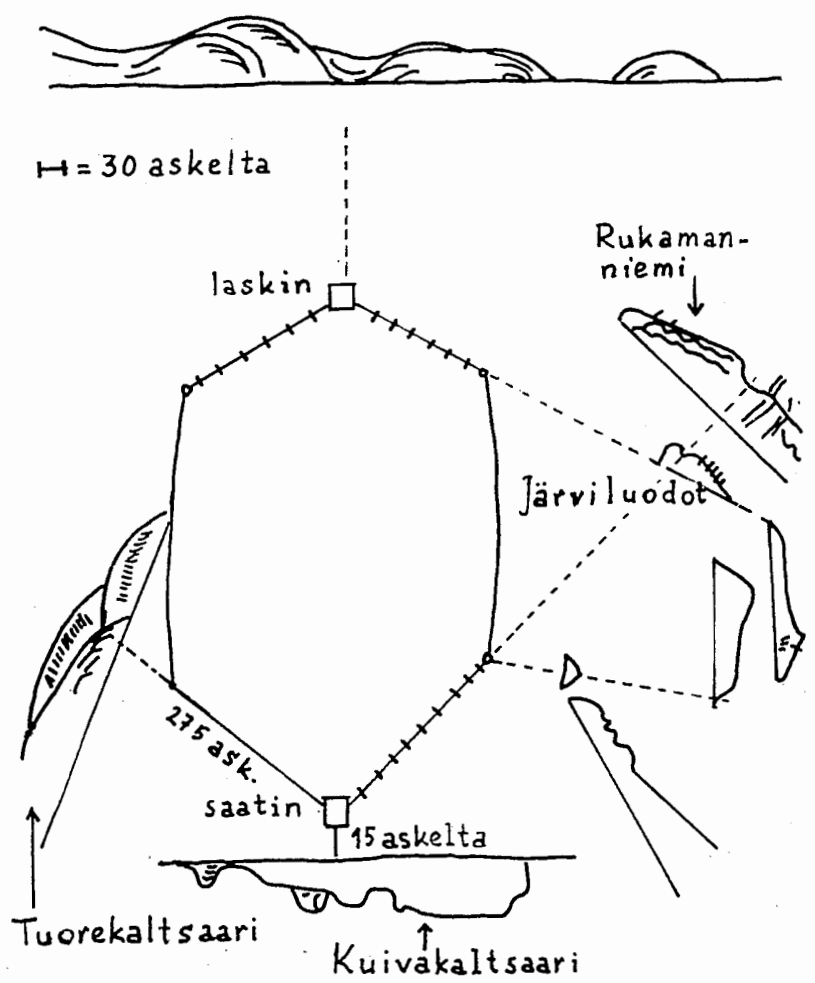

Kuva 3. Pakinaisten eteläpuolella sijaitsevan Kaltsaaren luoman kartta, kopio Hemmi Teleniuksen (s. 1891) nuottakirjasta. Lähisaarten ääriviivat on merkitty tarkasti, merkittävät kohdat on korostettu, joten ne eivät vastaa luonnonmukaista mittakaavaa. Etäisyyksissä ei liioin ole pyritty noudattamaan mittakaavaa, mikä olisikin mahdotonta, sillä esim. tässä laskimen yläpuolella näkyvä Maskinnanmaan pohjoiskärjen lähellä sijaitseva takamerkki (laakso) on Korppoon puolella yli $3 \mathrm{~km}: \mathrm{n}$ etäisyydessä laskimesta.

hakataan myös rehtoläpiä, työssä ovat osapojat. Näin työ joutuu, ja uitot voidaan työntää laskimelta jään alle. Luoma on tullut avetuksi ja on valmis vedettäväksi. - Saatin- ja laskinhako jäävät koko talveksi pystyyn paikalleen melkiksi, ettei kukaan sortuisi sulaan ja että nämä paikat olisivat helposti uudelleen löydettävissä. Ne ovat jäämerkkeinä kuten talviteiden reimihaot. 
Harvoin kuitenkaan luoma on näin symmetrinen. Lähellä laskinita, toista polvea tai rehtoa voi olla kiinnin, useimmiten kivinen riutta, joka on väistettävä. Silloin on joko toista polvea lyhennettävä, laskimen kulma muutettava - tehtävä enemmän suulle luomaan päin eli supistettava - tai tehtävä vääjyy ${ }^{11}$ eli kiertoliike kiintimen ohi. Tällöin on nuotankuninkaan muistettava tarkoin askelten luku ja suunnat (kuva 2). On vaikeasti avattavia luomia, joissa on pari kolmekin vääjyytä.

Hyvämuistinen kuningas saattoi pitää mielessään usean luoman maamerkit ja askelluvut. Mutta kun talvinuottakalastuksen jatkuvasti voimistuessa etsittiin luomia yhä lisää, niin alettiin luomista tehdä kirjallisia muistiinpanoja.

Kirjalliseen työhön tottumatonkin kuningas saattoi piirtää itselleen kuvan luoman paikan määräävistä maamerkeistä. Hän ei piirtänyt tavallista kanttaa, vaan hän ajatteli itsensä luoman piiriin ja merkitsi paperille luomaa määräävien saarten kontuurit ja veti niistä asian vaatimat linjat (kuvat 3 ja 4 ). Näin tehdessään hän menetteli kuin entisajan merenkulkijat, jotka purjehtivat maamerkkien mukaan seuraten horisontista rannikon piirteitä ja siellä eri maastokohdista muodostuvia suuntalinjoja. Tällä tavoin merkit piirrettiin myös vanhimpiin purjehdusoppaisiin (kuvat 5 ja 6). Ratkaisematita tässä jää, ovatko nuotankuninkaat oppineet tämän muistiinpanotavan vanhoista purjehdusoppaista vai onko kyseessä oma luontainen ympäristön kuvaus. Edellisen vaihtoehdon puolesta puhuu piirretityjen ja painettujenkin ns. portolano-karttojen eli rannikonkuvasten vanhuus ja yleisyys. Välimeren piiristä niitä on säilynyt 1300 -luvun alusta saakka. Suurenmoisen eteviä ovat hollantilaisen Lucas Janssz Waghenaerin piirtämät ja painatitamat "Spiegel der Zeevaerdt" (Leyden 1584) ja "Thresoor der Zeevaerdt" (1592), joissa myös Itämeren purjehduspiiriä on tarkoin kuvattu ${ }^{12}$. Useiden rantojen luonteenomaiset kon-

${ }^{11}$ Murt. vääjy, johdos verbistä vääjätä 'väistää, gå ur vägen för ngn' (Löunrot) < ruots väja 'vika undan för' (Hellquist).

${ }^{12}$ A. E. Nordenskiöld, Periplus. Utkast till sjökartens och sjöböckernas äldsta historia, Stockholm 1897, s. 101-; Eirik Hornborg, Segelsjöfartens historia, 2. uppl., Helsingfors 1948, s. 312. - Helsingin yliopiston kirjaston Nordenskiöldin kokoelmassa on viisi 1500-luvun lopulla hollanniksi, latinaksi, espanjaksi ja ranskaksi painettua Waghenaerin purjehduskirjaa, kaikki foliokokoa. Jo ensimmäisessä painoksessa on mukana Suomenlahden etelärannikko ja itäosa selityksineen Viipuriin saakka (II, 1585, kartta XI). Suomen ranta puuttuu. 


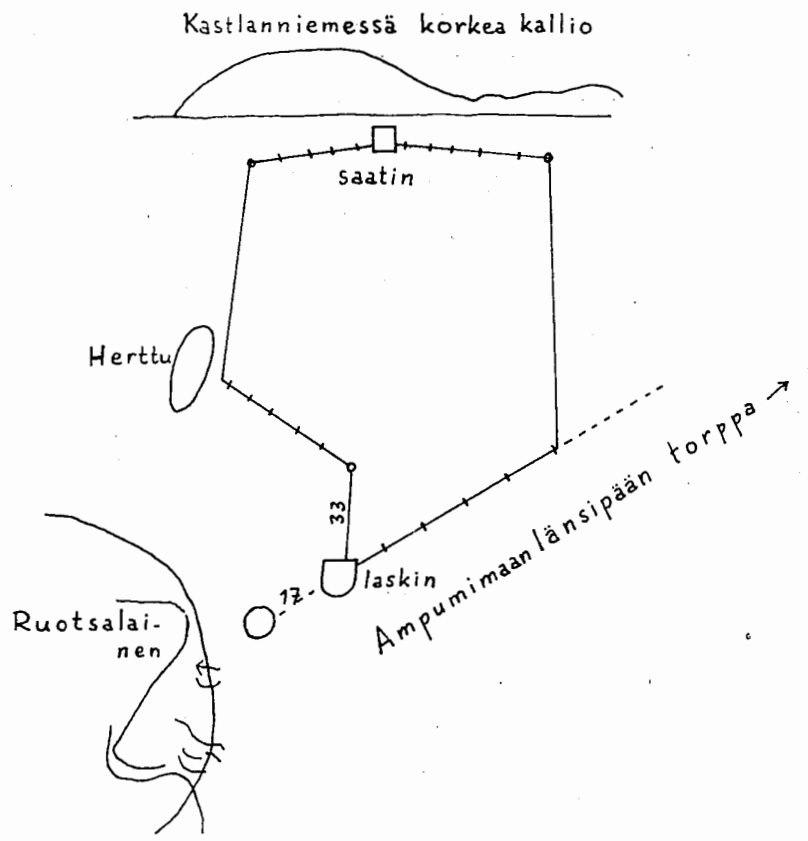

Kuva 4. Kastlanniemen luoma Rymättylän länsiaukossa, kopio Hemmi Teleniuksen nuottakirjasta.

tuurit, maamerkit, on myös piirroksin kuvattu sellaisina kuin ne horisontissa ottavat purjehtijan silmään. Näitä "meripeilejä" on ilmestynyt useina laitoksina ja monina painoksina. Myös suomalaiset talonpoikaispurjehtijat ovat omistaneet niitä ${ }^{13}$.

Merkillinen ja arvokas opaskirja Rymättylän talvinuottaluomista syntyi jo viime vuosisadan alkupuolella. Sen sai v. 1842 valmiiksi Rymättylän tunnetuin nuotankuningas Jermun Juha. Hänen erikoislaatuinen työnsä ansaitsee lähemmän tarkastelun.

Juha Juhanpoika syntyi Rymättylän Heinasten Jermun talossa 14. lokakuuta 1778 ja kuoli samalla tilalla 6. toukokuuta 1849. Jo poikasena hän kulki ensin lorvina, sitten osapoikana Kuristen nuotan mukana. Vanhempi veli otti kotitalon haltuunsa, ja Juha jäi vain setämieheksi, jolle rakennettiin pieni tupa Jermun maalle. Kun hän

13 Vanhaa ja kookasta purjehdusopasta säilytetään mm. Himangan kotiseutunıuseossa: Claas Jansz Voogt, De Nieuwe Groote Lichtende Zee-Fakkel. (V. 1760 kannessa erikseen musteella.) 


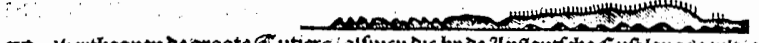

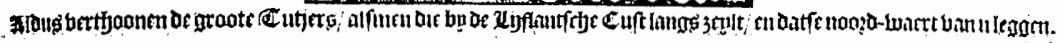

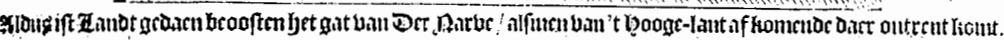

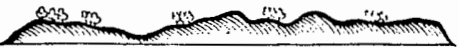

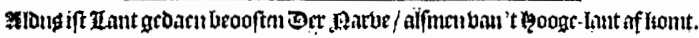

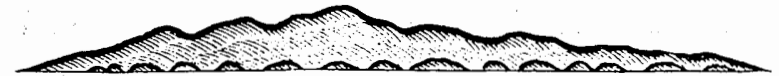

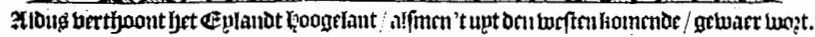

Kuva 5. Tytärsaareil (Tutjer's) ja Suursaaren (Hooge-lant) kangastuspiirteet eri srunnilta nähtyinä. (De Lichtende Colomne ofte Zee-Spiegel,... Amsterdam, Gedruckt by Pieter Goos, Anno 1658, s. 103.)

näin oli tavallaan maaton, hän ei voinut silloisen tapalain mukaan olla nuotan osakkaanakaan. Sen sijaan hänet jo nuorena valittiin Kuristennuotan kuninkaaksi. Tavallista ennen olikin, että kuningas ei ollut nuottuudessa osakkaana: hän oli vain etevä ammattilainen; seutukunnan taitavin ja tietävin mies, joka sai palkkansa päivälaaloina saaliin mukaan. Jäällä hän oli melkein yksinvaltias, kuitenkin hevos- ja uittomiehet, jotka olivat samalla osamiehiä, muodostivat ikään kuin esikunnan, jonka kanssa kuningas neuvotteli tärkeimmistä asioista.

Kuningas on ollut tapana valita aina vain yhdeksi pyyntikaudeksi kerrallaan. Jermun Juhan vaali uusiintui yksimielisesti vuosikymmenten ajan. Pitkäaikaisessa toimessaan Juha tuli tuntemaan Rymättylän kalavedet tarkempaan kuin kukaan muu. Hän ei tahtonut viedä suurta kalavesien tunitemustaan hautaan, vaan ryhtyi vanhemmalla puolen ikäänsä kirjoittamaan muistiin kunkin silloin tun-

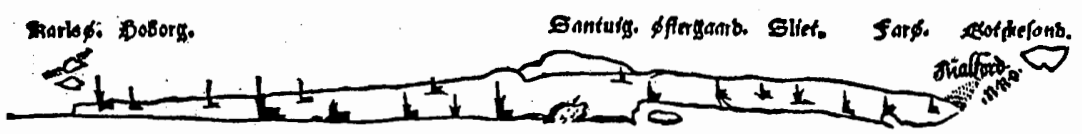

Kuva 6. Gotlannin kangastuspiirteet itäpuolelta nähtynä. Pienennys Laur. Benedichtin "Merikartasta" (Kööpenhamina 1568) A. R. Nordenskiöldin mukaan. Suomalaisten kannalta mielenkiintoinen on karttaan merkitty Hoborg 'korkea linna', ruotsiksi myös Hoburg ja Hoberget. Lounais-Suomessa näet on kerrottu tarinaa rikkaasta "Hooperin äijästä" (Kotiseutu 1910, s. 272-4). Varsinainen Hoberget on Gotlannin eteläisin kärki, $37 \mathrm{~m}$ korkea kalkkikivikallio, joka nousee suoraan merestä. Laki on tasainen, joten vuori kaukaa katsottuna näyttää miehen hatulta $j a$ on sellaisena oivallinen maamerkki. Vuoressa on useita luolia, joita paikallistarinain mukaan Hobergsgubben (Korkeavuoren ukko) on käyttänyt asuntonaan. (Nordisk Familjebok 6, Sth. 1883, p. 1349.) 
netun luoman maamelkit ja niiden lukemistavan. Juha ei kuitenkaan osannut kirjoittaa, vaikka olikin lukumies. Mutta tämä ei riittänyt esteeksi. Hän otti aapisestaan latinalaisen kirjaimiston malliksi ja alkoi tekstaten muodostella välimerkittömiä lauseita ja sanajaksoja paperille, joista kyllä kalastajat saivat selvän. Vihdoin 1842 hän sai tekstatuksi 49 luoman topografiset selitykset vihkoon. Kirja tuli heti jokapäiväiseen käyttöön, sillä pian tämän jälkeen alkoi nuottakuntien lukumäärä lisääntyä, koska nyt jo voitiin ostaa lankoja ja köysiä eikä kaikkea enää tarvinnut valmistaa kotona. Kuninkaan virkoja tuli lisää, ja ilman Juhan kirjaa olisi monen ollut mahdotonta avata luomaa. Kalastuselinkeinon uusin nousu pohjautui osaksi siis myös Juhan kirjaan, joka kului nopeasti nuottajäällä loppuun. Kopion siitä 1864 pelasti Zefanias Suutarla ${ }^{\mathbf{1 4}}$, Rymättylän Suutarlan isäntä, kalastaja ja valtiopäivämies. Seuraavana vuonna Suutarla jatkoi kopiointiaan lisäten kirjaan vielä 13 talviluoman selitystä. Nekin ovat Jermun Juhan merkintöjen mukaan, kuten käy ilmi lisäyksen alkusanoista: "Lisäys entiseen. Saman miehen kirjoituksista uloskirjoittanut wuonna 1865. Myös vähän oikoen. Zef. Gustaanpoika." Suutarlan kappaleen kopioi 1881 Luonnonmaan Käkölän isäntä Petrus Augustinus Nummelin (1835-1925). Toisen kopion teki mm. Koisaaren isäntä Karl Theodor Karlsson (1859-1941). Useita muitakin kopioita tiedetään tehdyn. Käkölän isäntä jatkoi kirjaa 33 uudella selityksellä, joihin Luonnonmaan Kirstilän isäntä August Grönroos oli lisännyt vielä 8 apajaa. Nyt talvinuotta-apajia tiedetään Rymättylän, Nauvon, Iniön ja Kustavin tienoilla yli 250.

P. A. Nummelinin 1907 kirjoittamista innostavista sanoista käy selkeästi ilmi, millaisen arvon kalastajat antoivat Jermun Juhan kirjalliselle työlle. Mm. seuxaavan tapaiset lauseet ovat koottavissa hänen kuvauksistaan: Meidän nykkyiset kymmenet nuotankuninkaat tietäkööt, että vuosisatoja on merkille pantu talvinuottaluomia. Mutta muistakoot ja kunnioittakoot enemmän vielä sitä miestä, joka tiedot säilytti kaikille, tuota tasaista, vähäpuheista oikonenäistä miestä punaisenruskealla, tarmokkaannäköisellä naamalla. Hän oli tanakka, ryhdikäs ja vähäläntä, katsellen tarkkaavasti leveän ja samalla kor.

${ }_{14}$ Zefanias Suutarlasta lähemmin ks. Saini Laurikkala, Zefanias Suutarla 1834-1908. Suomen talonpoikia Lallista Kyösti Kallioon, s. 454-461, PorvooHki 1952. Samassa teoksessa Kustaa Vilkunan esitys Jermun Juhasta (s. 215217 ). 


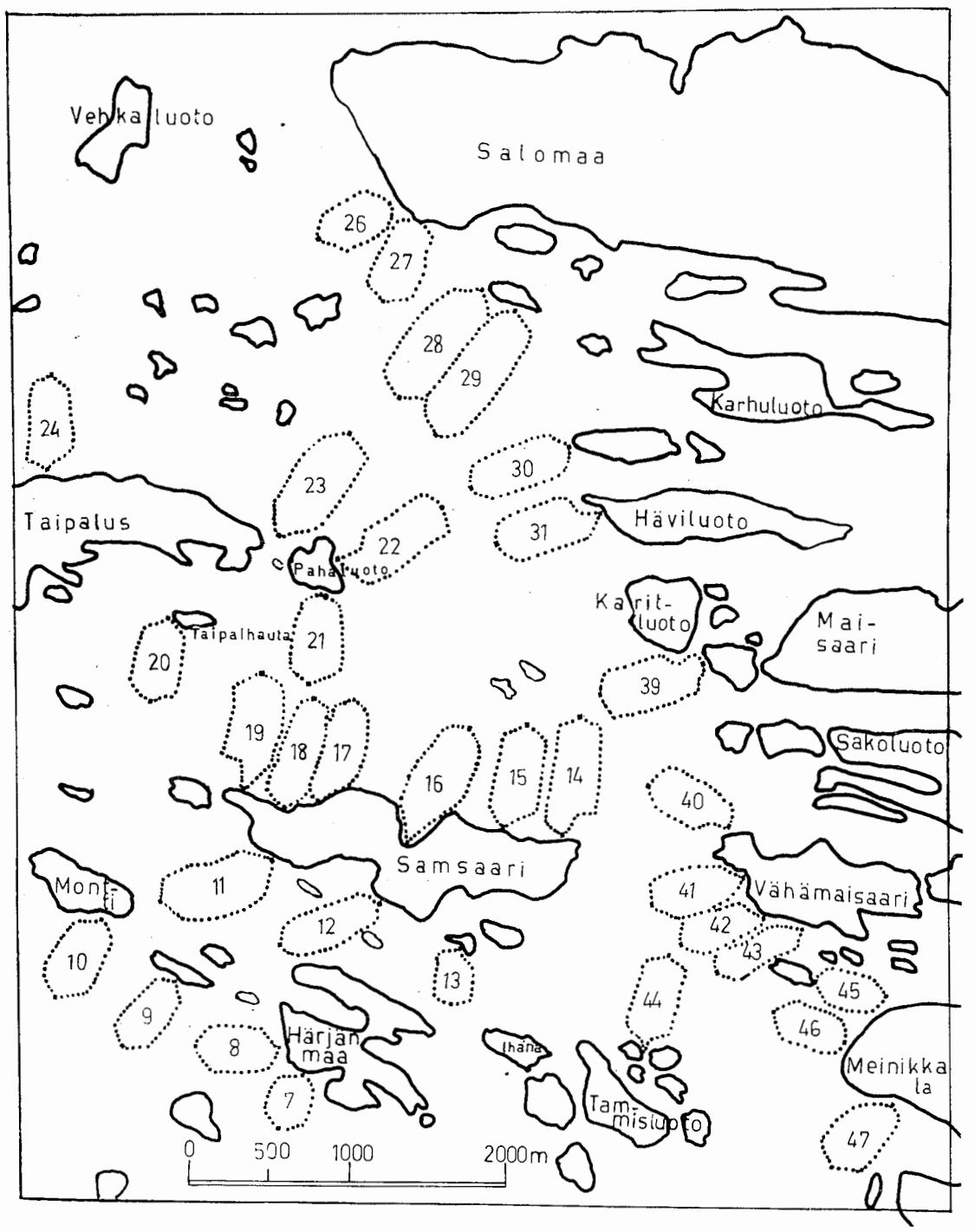

Kuva 7. "Kartta Omenaisten aukolta Rymättylästä." Kartta on osa isommasta, 1935 Einari Vuorelan tekemästä kartasta, jonka hän oli piirtänyt Rymättylän pitäjän vesijakokartan, valtion vesialueen kartan, Nauvon pitäjän vesijakokartan ja merikortin mukaan ja johon hän oli merkinnyt nuottaluomat muistitietojen perusteella ja käytännössä olevien korko- ja takamerkkien mukaan. Nuottaluomat ovat seuraavat: 7 Härjämaan kolaus, 8 Härjämaan kärki, 9 Huhtakari, 10 Montti, 11 Samsaaren-pääluoma, 12 Knappari, 13 Ihana, 14 Falkki, 15 Luola, 16 Haikanperä, 17 Mustaperä, 18 Torpanperä, 19 Uusiluoma, 20 Taipalhauta, 21 Pikanelli, 22 Pahaluoto, 23 Tössi, 24 Ansuluoma (25 ylempänä kartan ulkopuolella), 26 Kiviperä, 27 Kuolinniemi, 28 Vähähänni, 29 Isohänni, 30 Anosin, 31 Häviluodonpää, 39 Kolkka, 40 Kumpeli, 41 Tumppi, 42 Sätkä, 43 Natsu, 44 Pöllö, 45 Mörssäri, 46 Meinikkalanniemi, 47 Letto. - Kartan omistaa maanvilj. Otto Pakkanen, Rymättylä kk. 
kean otsan alta. Ohjasi hyväntuulisella äänellä osapoikien ja päiväläisten töitä pyrystä ja pakkasesta välittämäittä. Vahvoissa pikisaumasaappaissaan, kotona valkatuissa harmaissa kangashousuissa, pystykrainen isotröijy ja lammasnahkainen liivi päällä, pörölakki päässä hän kävi jäällä. Hän ei tehnyt hyvää työtään omaksi edukseen vaan koko paikkakunnalle. Ei hän ollut nuottuuden osakas, oli vain setämies, jonka ei tarvinnut harrastaa lastensa etua. Hän oli alaansa innostunut ammattimies, joka pelkästä velvollisuuden tunnosta teki suuren hyvän työnsä. — Kopiokirjansa kanteen Nummelin on 1881 merkinnyt sanat: "Jermun Juhan kirja on talvinuottalaki, kuten sitä kutsuvat. Sillä niitä luomia kun tässä on mainittu, ei saa mistään ääreltä loukata”. Myöhemmin Nummelin on kertonut muutamien nuorempien nuotankuninkaiden uteliaisuuttaan kokeilleen, miten tarkat tiedot Jermun Juhalla on ollut, milloin hän on yksityiskohtaisesti ilmoittanut luoman eri osien paikat. "Mutta kalliiksi se koe on tahtonut käydä. Päiväinen työ ja hailit on menetetity, krekkonaisia verkkoja osakkaat ovat saaneet hyvistä pyytimistään."

Nuotitaluomia luonnehtiessaan Jermun Juha sanoi vain sen, mikä oli välttämätöntä, nimittäin kulmapisteiden ja vääjyiden paikat. Hän ei sanonut, missä kohti on kiintimiä, mutta jos laskimen, saattimen ja polvien paikka oli ilmoitettu yksityiskohtaisen tarkasti, merkitsi se sitä, että aivan lähellä luoman ulkopuolella on kiinnin, jota on syytä varoa. Jos taas nämä seikat oli ilmaistu vain suunnilleen, voitiin esim. luomaan "lyödä korkoa lisää" eli vetää apaja pidempänä.

Valitettavasti Jermun Juhan alkuperäinen käsikirjoitus ei ole säilynyt, mutta sen kopion kopio vuodelta 1881 on vielä tallella. Siinä näkyy jo kahden suomen kielen kirjalliseen käyittelyyn tottuneen talonpojan korjausten vaikutusta - usein esim. korkeus pro korko, korkeusmerkki pro korvonmerkki, yms. P. A. Nummelin onkin kopionsa kansilehdellä huomauttanut, että Zefanias Suutarla on kopionsa (1864) "vähä oikoin uloskirjoittanut". Omasta puolestaan Suutarla, jolka oli syntynyt Merimaskussa eikä ollut varsinainen nuottamies, on huomauttanut: "Jos olisin ollut tuttu paikkakuntain ja niiden nimien kanssa, niin olisin voinut enämmän vääränpuolisia lauseita oijentaa, muutamia mitättömiä poijeskinjättää ja muuton parannella, mutta peljäten sisällyksen jossakin kohdassa muuttuvan, on tämä täytynyt lähes sanasta sanaan uloskirjoittaa.” Tämä viittaa 
siihen, että ainakin ensimmäinen kopio oli mahdollisimman tarkka. — Tässä yhteydessä on syytä jullkaista näytteitä tästä ainutlaatuisesta "talvinuottalain" käsikirjoituksesta P. A. Nummelinin kopion mukaan.

$\mathrm{N}: 0$ 1. Haijasten Kotkan Matalan luoma: Saatin on päivänpuolella sitä aidan johdetta, kuin on pohjanpuolella Kotkaankarin luomaa Haijasten maan rannalla, arvaten niin ulos rannalta, että on $1 \frac{1}{2}$ syltää syvältä vettä. Takamerkki on Peräisten rantaniemi. Korvonmerkki on kuin Hanhenranta ja Särkänluodon niemi alkaavat tehdä kolmea: siinä laskin. Aukkopolvet luomaa päin sulkuun enemmän kuin suorakulmaan. Sitte tavallinen talvinuattaluoman laajuus.

$\mathrm{N}: 0$ 2. Kotkaankarin pääluoma: Saatin on sen ensimmäisen karin niemen kohdalla kuin on päävän puolella sitä rantaperää, kuin on Matalan luoman saattimesta. Karin saatin on tehtävä niin ulos rannalta, että ne karit, kuin ovat Haijasten rantaa päin, näkyvät hyvin ulos takaa. Takamerkki on iso kivi, kuin on korkealla vuorella päivän puolella Peräisten rantalahtea. Korkeusmerkki: Koska Hanhenluodon ranta ja Särkänluodon ranta tuleevat kolmea; siitä lasketa on, eli tehdän laskin. Aukkopolvet supistetaan enämmän, kuin suorakulmaan, luomaapäin sulkuun, ja tavallinen talvinuotan laajuus.

$\mathrm{N}: 0$ 3. Kotkaankarin jälkiluoma: Saatin sama kuin pääluomanki. Takamerkki on Mustan pohjanpuolinen niemenkulma. Korkeus sama kuin pääluomanki, taikka pääluoman aukkopolvella. Luoma muuton niinkuin vaatii, kuitenkin, että päivänpuolinen maapolvi käydään saattimelta, päin sitä isoa kiveeä, kuin on Leiklahden niemen rannalla, ja pohjanpuolinen maapolvi saattimelta, päin Hämölän vanhaa rantaperää, jotka ovat samat, kuin karin pääluomankin maapolvet.

N:o 4. Mustaan pääluoma: Saatin on tehtävä siihen vanhan Mustanniemeen torpan huoneiden alapuolla, eli kohdalla, ja niin ulkona rannalta että ne Mustanniemen niemet tekee kolmea. Takamerkki on se vähäinen perä, kuin on pohjanpuolella Kirstilän rantalahtea. Korkeus on, kuin Kotkanvuori ja Tärkkisten Kalpin niemi tuleevat yhteen. Pohjanpuolinen aukkopolvi päin Hanhenluotoa ja siitä päin Peräisten rantaa, ja päivänpuolen aukkopolvi päin Leiklahden nientä ja päällepannan se Mustanniemen vuori. Päivänpuolen maapolvi käydän saattimelta päin Rohdinkaisten luotoa (nientä). Pohjanpuolen maapolvi päin niitä kareja, kuin ovat pohjanpuolella Wennanpaltan torppaa Luonnonmaan saaren rannalla.

$\mathrm{N}: 0$ 5. Mustaan jälkiluoma: Saatin sama kuin pääluoman. Laskin pääluoman pohjanpuolisen aukkopolven takana, taikka aukkopolvelta. Aukkopolvet niinkuin vaatii, sitte tavallinen talvinuottaluoman laajuus. 
N:o 6. Petkellahden pääluoma: Saatin on siinä, kussa se kallistunut vuori on, Leiklahden rantalahden päivänpuolisella sivulla. Vähän idänpuolella sitä kallistunutta vuorta on yksi leppä, jossa on saattimen paikka, viidenkymmenen kyynärän pailkoilla rannalta. Takamerkki on Luonnonmaan Kirstilän rakennus (pytingi), eli keskellä rantalahtea, niin että Leiklahden rantahuoneet ja Kirstilän rakennus tekevät kolmea. Korvon merkki. Koska Kotkanvuoren niemi ja Tärkkisten Kalpin niemen vuori tulevat yhtä tekemään, niin tehtälköö siihen laskin. Päivänpuolinen aukkopolvi päin sitä vuorta kuin on Tirhanluoman saattimen ja Tirhan peräksimen välillä, ja aukkopolvelta mennän päivänpuolella Leiklahden niemen vuoren sivua päin. Saattimelta käydän ulos, päin Kirstilän lahtea, niinkauas että Suurempään Rantala ja se "Savikari" joka on liki Mustanniemen rantaa, tekevät kolmea. Sitte käydään vääijy Suurenpään Rantalan torppaa päin, taikkła vähän idänpää. Pohjanpuolinen aukkkopolvi käydään päin Hanhenluodon nientä, sillon kuin luoma on täydessä korvossa, ja sitte aukkopolvelta ("päällepannan") päin sitä metsän sivua, kuin on Leiklahden ha'an-kedon pohjanpuolella. Saattimelta käydän polvi ulos, päin Wennanpaltan torppaa, niinkauvan että rehdot sopii yhteen.

N:o 7. Petkellahden jälkiluoma: Saatin sama kuin pääluomankin. Laskin pääluoman päivänpuolisella aukkopolvella samassa korvossa pääluoman kanssa, aukkkopolvet kuin luoma vaatii; sitte tavalilinen talvinuotta luoman laajuus, niin että pohjoispuoliselta aukkopolvelta mennän sitä karia päin, kuin on Mustanniemen rantaa likellä, ja päivänpuoliset rehdot vähää ulkopuolella pääluoman rehtoja, mutta vääijystä sisälle.

N:o 8. Tirhan luoma: Saatin Tirhanperän puolella sitä niemen päätä joka näyttää melkeen Karin kaltaiseksi; lännen puolella sitä vuorennientä, joka on Raumluotoa vastaan, mutta viiden-kuudenkymmenen kyynärän paikalla erinänsä niemestä Tirhanperää päin, mutta jotenkin niemispään kohdalla ulos Ruokorauman laitumen rannalta. Takamerkki siitä se iso kivi, joka on Kirstilän lahden päivänpuolisen niemen vuorella. Korvonmerkki sama, kuin Petkellahdenkin. Aukkopolvet, kuin luoma vaatii, aina enämmin luomaa päin koolle, kuin suoralkulmaan (vinkkkelin) aulkkopolvelta tavallinen luoman laajuus, kuin ymmärtävä mies kohtuulliseksi näkee. Päivänpuolinen maapolvi käydään saattimelta päin Rohdinkaisten torppaa. Pohjanpuolen maapolvi päin Leiklahden nientä.

N:o 24. Karhun Otan luoma: Saatin päivänpuolella Karhunpäätä, siinä jossa se ensimmäinen ketomäki, Karhunpäästä länteenpäin on, jonka ketomäen rannalta käydään viisikymmentä askelta päin Paavaisten nientä, jossa juuri on saattimen paikka. Takamerkki on se vähäinen vuorikallio keskellä Kaarniitan lahden perää. Korvon- 
merkki: kuin Warsaluodon länsipään ranta ja Lapilan Pitlkän länsipään vuori, joka on liki Saappan luoman saatinta, tekeeväit kolmea. Päivänpuolen aukko [:aukkopolvi] päin Weljisten päätä, ja rehdot sitte keskellä Kuuttonientä; samanpuolen maapolvi saattimelta päin Paavaisten niemen ja Isonternin väliä. Pohjanpuolen aukkopolvi, päin Kirjalan Petälkaria ja rehdot päin Karhunpään päiväkulmaa, taikka keskellä Karhunpäätä. Maapolvi, saattimelta päin sitä isoa kiveä, joka on Warsaluodon pohjoispuolisella rannalla, niinkauas, etiä Heinasten lahden saatin ja Lapilan muuri tekeevät kolmea, sitte käydään vääijy päin Lapilan kivimuuria.

$\mathrm{N}: 0$ 25. Karhun Haaran luoma: Saatin sama kuin otanki luoman. Takamerkki on Kaarniitan Siikakari. Korvonmerkki on sama, kuin Otanki luoman. Aukkopolvet kuin luoman luonto vaatii. Maapolvet sisälle otan luoman saattimelle.

N:o 26. Karhun pääluoma: Saatin on sama kuin Haaran ja Otan luomienki. Takamerkki on Wepsän kloppi. Korvonmerkki on Wansaluodon länsipään ranta ja Kuulisten talvinuotita saatin kolmea. Aukkopolvet tavallisesti suulle. Rehdot samoin, kuin luoman luonto tavallisesti vaatii.

$\mathrm{N}$ :o 27. Heinostenlahden luoma: Saatin Kuristen Mariniemen niitun rannalla Heinostenlahden puolella, siinä perälksimessä, kuin on Kuuttonientä vastapäätä. Takamerkki on, kuin Wallisten tuulimylly näkyy Heinostenlahden puolelta Kuuttoniemen metsän [:yli]. Korkeudessa ei ole mitään määrää. Rehdot niinkuin luoman luonto vaatii; samoin aukkopolvet, mutta Mariniemen kulmasta erotetaan rehdot uiton mitan erinänsä rannalta. Pohjanpuolen rehdot päin Kuuttonientä ja Maapolvi päin Karhunpään keski-rantaa.

N:o 28. Ruohokarin luoma: Saatin on päivänpuolella Ruohokarin kulmaa. Eroitetaan vähää rannalta päin suvinuottasaatinkaria, että se leppä, kuin on sen suvinuotta saatinkarin päällä ja pisin Ruohokarin niemi luonnonpuolella, tekevät kolmea saattimen kanssa. Takamerkki on Wepsän tarhahuoneet kolmea Ruohokarin kanssa. Korkeus on, kuin Kirjala rantahuoneet näkyy Karhunhaikan ylitse. Päivänpuolen aukkopolvi päin Heimluodon raumaa ja sitte rehdot päin Heimluodon pohjanpuolisen vuoren sivua. Siitä isosta vuoresta astutaan ulos viisikymmentä askelta päin Kuristen Marinientä; josta taas pannaan rehdot päin Poronkulmaa, kuin ensin on Poronkulmasta astuttu päin Weljestenpäätä viisikymmentä askelta ja jossa on polviläpi. Siitä käännetään rehdot jälleen päin Paavastenmaan rantaa. Saman puolen maapolvi käydään saattimelta päin Heimluodon rauman puolista nientä. Pohjapuolen aukkkopolvi, päin Kuristen Marjaniemen perää, ja siitä rehdot päin Raidasten haikkkaa, niinkauas, että maapolvi on käyty saattimelta päin Alaskunnan saattimen rantaan, jossa on rannalla joku koivupuu. 
N:o 59. Ketun Säären luoma: Saatin on siinä missä see laavavuori ja yksi väärä mänty ovat Waljumaan idänpuolisella rannalla: Laskin astutaan r'unsaasti kahdeksankymmentä askelta siitä karista joka on idänpuolella Waljunmaata päin Ketun maata, tai maan nientä. Muuton on luoma puhdasta, koska siinä on jälkiluoma molemmin puolin. - Pohjanpuolinen jälkiluoma saatetaan pääluoman saattimeen. Mutta päivänpuolisen jälkiluoman saatin on sen perän poskelila (kupeella) joka on päivänpuolisen niemen tykönä.

P. A. Nummelinin ensimmäisenä kirjaamista luomista valittakoon esimerkiksi n:o 6, Rohdinkaisten pääluoman selitys siihen liittyvän kuvaavan historian takia.

N:o 6. Rohdinkaisten pääluoma: Saatin knin Kuhnan luomankin. Takamerkki saattimelta päin Isotärpänän itäpäätä. Korvonmerkki Isoharteen keskikohta ja Raumluodon Harmakarin keskikohta tekevät laskimen kanssa kolmea. Aukkopolvet kuin luoma vaatii. Idänpuolinen maapolvi saattimelta päin Loheperää ja lännenpuolinen kuin luoma vaatii.

Huom. Tämä luoma on siksi vaarallinen että sitä pitää vetää niiden tamholtttien jälkeen kuin edellisessä muistiinpanossa sanotaan. Sillä pää- ja kulma luomien välillä on sellainen "haka" joka vissin pitää jos nuotta sen taanne joutuu. Tämän hakan keksei Luonnonmaan talvinuotta talvella 1882. Silloin olin itse nuotalla ja laskimme nuotan päin Isotärpänän raumaa eli Iso- ja Vähätärpänän väliä kohti samaan korkeuteen kuin nykyään pääluoma vedetään. Silloin toisella vetimellä otti nuotta kiinni joka loti täytyi uittaa takaisin ja saatiin se laskimelta ylös. Nuotta ei tullut revityksi. Seuraavana päivänä pantiin taukot yhteen ja vedettiin samassa paikassa köysinuottaa. Silloin taukot tarttusivat lujan hakan taanne. Taukot tekivät ristin jotka selvään näyttivät missä kohden on kiintin. Taukojen kanssa käytiin, sitte kuin lännenpuolelta luomaa oli kovasti ottanut kiini, siten että hakattin läpiä suoraan linjaan taukon päälle ja otettiin koukulla taukon puhti aina ylös, niin tehtiin molempien taukojen kanssa, siksi, että tultiin ihan kiintimen päälle, joka havaittiin siitä, että taukot tulivat ihan luotisuoraan yhdestälävestä kiintimestä ylös, joka ei ennen helponnut kun hakattiin joku läpi aukkoa päin. Kiintin on saattimelta päin Isoakitua (Kitukari) niin ulkona että Käkölän Tammilkarin päivänpuolinen nokka ja Jaakolan Isoharteen Kojukarin pohjoispuolinen nokka tekevät yhteen ikään yhdeksi saareksi, niin ollaan ihan kiintimen päällä. Tässä paikassa on 20 syltää vettä, eikä tarkaammaliakaan luotimisella voinut veden syvyydestä eroitusta havaita, eikä riuttaa löytää. Taukossa se kohta kun oli kiintimen takana ja joka väänettiin kovin piukkan oli ikään vanhaa puumöhnää. 
Tämä oletuttaa ıtodeksi sen tarun joka kertoo, että Ruokorauman rusthollissa oli tytär jonka sulhasmies oli eräs kauppalaivan kapteeni Turusta ja joka oli eräänä myrskyisenä päivänä 17 vuosisadan alkupuolella lähtenyt parin merimiehen kanssa isolla laivanpaatilla vahvalla "paarlastilla" tullaksseen monsiamensa luoksi Ruokoraumalle, mutta johon ei kumminkaan saapunut ja on sillä tiellä venheneen miehineen päivineen. Jälestäpäin sanottiin erään Isokylän torpparin Hanhen rannalla löytäneen vesiajoilta herrasmiehen ruumiin joka arveltiin olevan saman kapteenin ruumis. Torppari oli siitä ajosta alkanut tulla rikkaaksi mieheksi jotta voi otaksua siitä, kutei sanotun ruumin taskuissa ollut niitä joita oli ollut Turusta lähtiessä. Nim. kapteenilla oli ollut paljon rahaa ja kallisarvonen kultakello taskussa kun piti mennä morsiamensa luoksi. Sillä tiellä kaikki ovat ijäisessä hämärässä. Sitä vaan luullaan jos mainittu laivan pargaasi olisi uponnut aivan siihen paikkaan Harten kurkulla missä yllämainittu "luja haka" nyt on ja joka oletuttaa siitäkin, kun veden syvyys on ihan tasainen eikä mitään kivikasan (riutan tapaista) sekä, että kun tauvoista jotka olivat kiintimen takana tuli ylös ihan sellaista vanhaa puumöhnää jota ei olisi voinut tulla jos tauko olisi ollut kiven takana.

Vielä otettakoon esimerkkki Kirstilän isännän August Grönroosin kirjaamista luomista. Vaikka hän oli edellisiä nuorempi, hän oli kirjalliseen työhön tottumattomampi kuin he.

Hohteen luomaa. Saatin tehdän, päivän puolella sitä aidan johrettaa kuin on peräisten maan rannaila Anttilan ja ylismattilan Metän välisä, ja vähän siitä johtesta on vuoren nokka eli niemi sen johtenosa Peräisten rannan välisä, ja siinä vuoren nokassa on kivi ja siitä kivestä 20 askkelta päin hanhen nokka, ja sillä kohdalla on saatin. Takamerkki on seen aidan johre kuin on pohjaan puollella, Kotkaan matalaa luomaan saatinta. Korkeus on kuin Tärklkisten kolpin niemi ja Kotkaan vuori tulee yhteen. Aukkopolvet niinkuin luomaan luonito vaatii. Päivän puolen maapolvi äsken mainitusta kivestä kuin on saattimen takanaa, peräisten rantaniemen pääsä, ja siitä päivän puolella Kotkan Karin nientä, Ja väijy on niin ulkona rannaltaa, että kiviniemen nokaasa oleva Isompi kiwii, Ja Lapilan metän kukkula teke suoran kolmea ja toissii kässi Hankan nokka ja Tuuleri metän ranta Ali porhon vuori tule yhiteen. Pohjanpuolinen maapolvi, siitä mainitusta kivestä kuin on peraisten rantaniemen pääsä, päin Kotkaan notkoa ja niin ulos rannalttaa että Kiviniemen nokasa oleva see isompi kivi ja korkiampi mettä Lapilan massaa tekee kolmea, Pari askelta siitä ulompa, toinen merkki, siitä ensin mainitusta raja aidasta saatinta päin on yksi vuoren rako, ja siitä raosta päin matalpään perän paljasta paikka kässin. Tämä on tarkka luoma maan likellä kiintimiin tähden. 


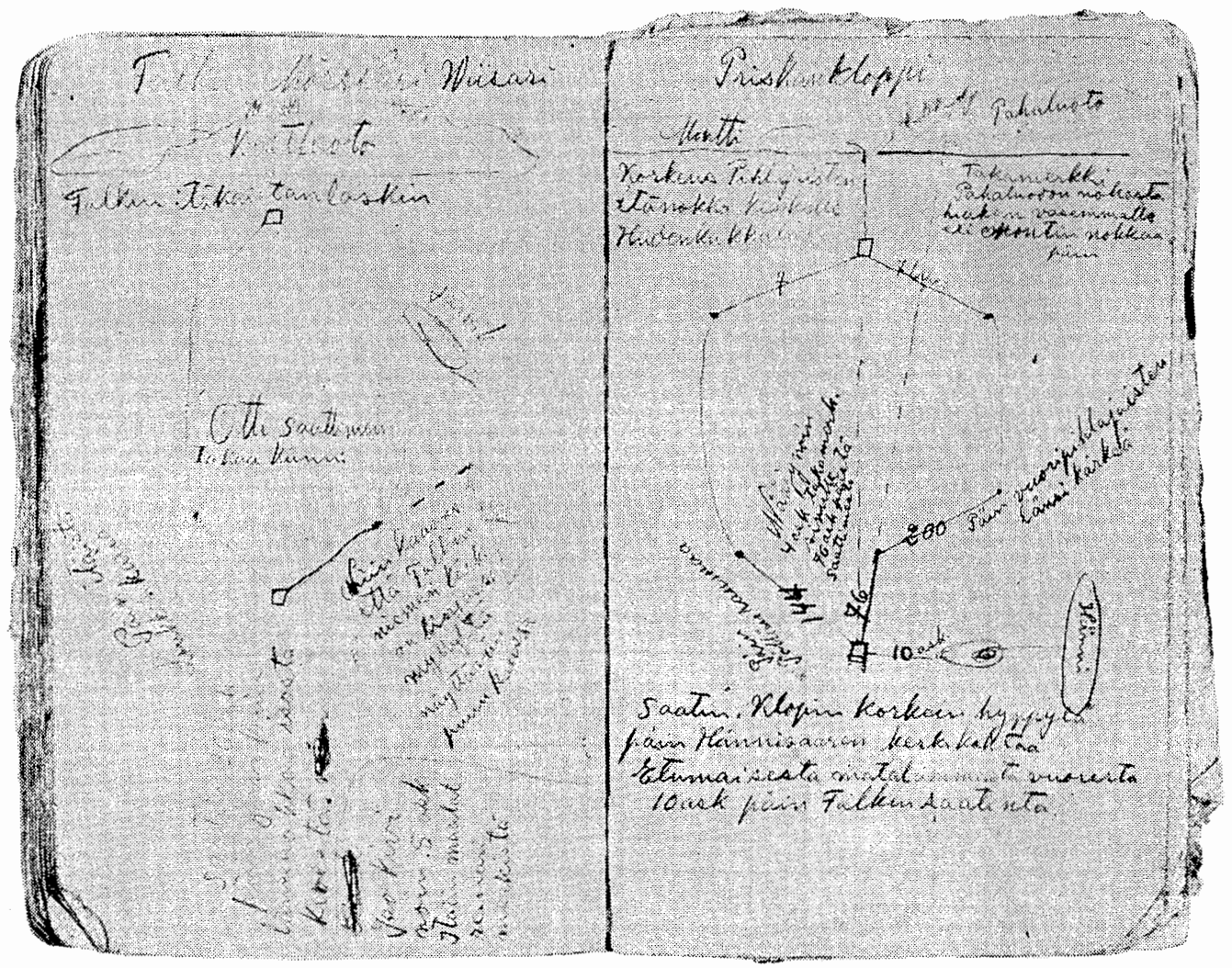

Kuva 8. Aukeama Hemmi Teleniuksen nuottakirjasta. Kirja on jatkuvasti käy. tössä, vaikka se on jo melkoisen kulunut ja himmeä. Nykyisin se on Eero Kustosen hallussa. Kirjasta on mikrofilmi Suomalaisen Kirjallisuuden Seuran arkistossa.

Nykyisin luoman avaajilla on käytettävissä merikortti ja kompassi. Vanhoilla luomilla niitä ei tarvita, mutta uusia pohjatasanteita etsitään yhä kauempaa ulkosaaristosta, jolloin maamerkkien lisäksi otetaan kompassin osoittamat suuntakulmat tueksi. Näytteenä uusimmista merkinnöistä esitettäköön Korpppoon Ison-Gyltön luoma, jonka Eero Kustonen on 1958 määritellyt nuottakirjaansa seuraavasti:

Iso-Gyltö. Saatin Isosta kivestä $97 \mathrm{~m}$ suuntaan $23^{\circ}$ päin matalaa riuttaa Stor-Utterskäristä etelään; Mossaskärin maitten päässä toinen saatin 10 ask. päin alinta kivipyykkiä niemessä. Kelön matala kohta niemen kärjessä. Pohjoispuoli saattimesta suuntaan $21^{\circ} 80 \mathrm{~m}$ päin 


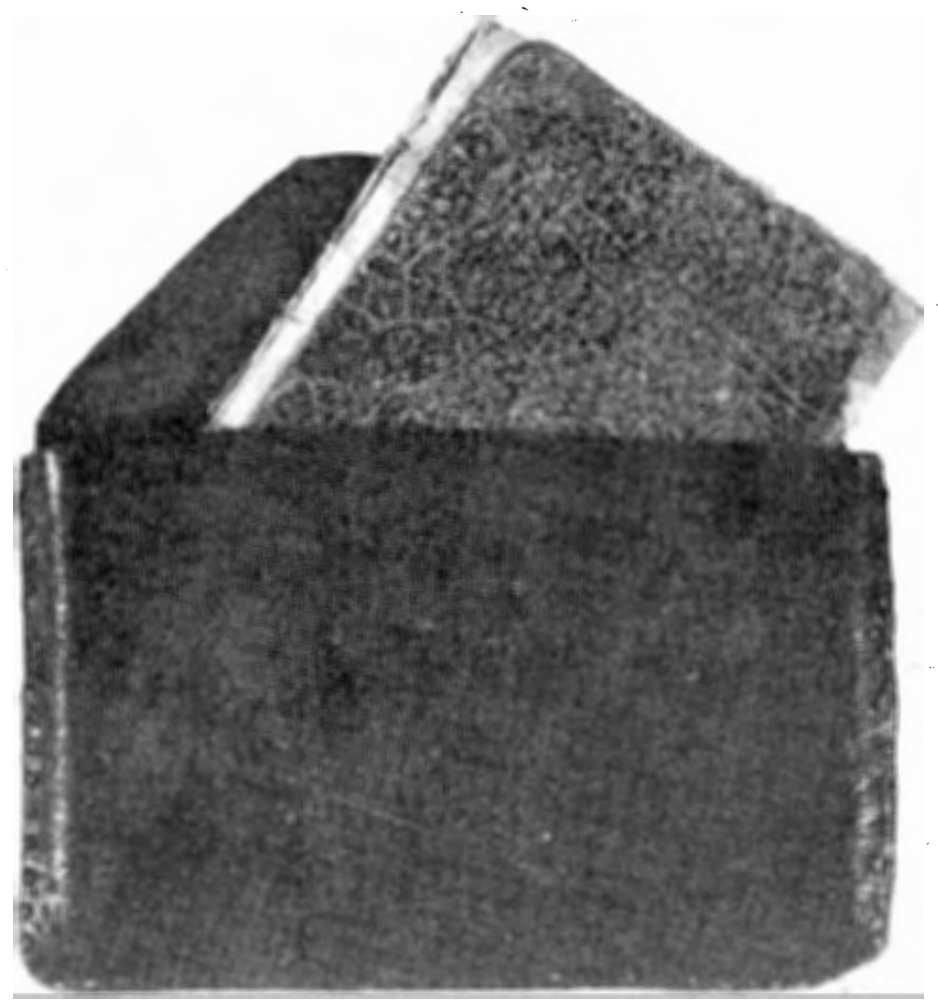

Kuva 9. Hemmi Teleniuksen nuottakirja ja sen tukeva nahkakotelo, joka sopii mukavasti ulkotaskuun. Koko noin $11 \times 17 \mathrm{~cm}$.

Stor-Utterskärin pohjoispäässä olevaa korkeampaa kalliota, kallion pääliä olevaa lovea. Siitä suuntaan $20^{\circ} 80 \mathrm{~m}$ päin Rönskäriä. Siitä edelleen 170 ask. suuntaan $17^{\circ}$ päin kallion pohjoiskärkeä, jonka takana on metsä, siitä suuntaan $16^{\circ} 198$ ask. e.m. metsäisen maan korkeimman kohdan ja kallion puoliväliä.

Eteläpuoli: polvi suuntaan $27^{\circ} 200$ ask. päin Brunskärin suunnalla näkyvää pientä riuttaa, jää 7 askelta kivipyykkien linjasta vaille. Edelleen päin Rönskäriä 160 ask. suuntaan 19,5. Suunnilleen kivipyykkien linjaa, pyykit niemen puolella suunnassa $51^{\circ}$ ja pohjoispuolella $4^{\circ}$, toinen on luonnonkivi, rannan puoleisen vääjyn kulmasta $26,5^{\circ}$ päin samaa pientä riuttaa kuin polvikin 130 ask.

Korko: Mossaskärin torppa näkyy Rönskärin länsikärjessä, kivipyykit maissa. Muurattujen linjasta 90 ask. pidemmäksi.

Aukkopolvet: pohjoispuoli päin kiviryhmää kalliolla. Etelän puoli Kaltholman ja Kelön keskivälille. Laskimen suunta saattimelta 19,5. Kivipyykit ison lohkareen eteläpuolella $(\mathrm{n} .10 \mathrm{~m})$ osoittavat laskimen 
suuntaa. Kompassi suuntaan $20^{\circ}$ alimmasta pyykistä, joka on iso kivi, päällä pienempi kivi. Saattimen suunta $21^{\circ}$ päin Stora-Uitterskärin pohjoispäässä olevaa kallion lovea.

Uudet luomat etsittiin vetämällä ohuen jään aikana köysinuottaa. Nuotan asemessa oli silloin vain paksu tauko, johon oli kiinnitetty kuten verkkojen kulmiin porhot eli kookkaat kivipainot, joten tauko vedettäessä kulki pitkin pohjaa. Ensin mitattiin suunnitellun alueen syvyys ja tutkittiin pohjan laatu. Mieluisin luoman syvyys laskimella entisaikoina oli $15-20$ syltä $(27-36 \mathrm{~m})-$ nykyisin 20 syltä tai yli — sitten tasasyvää ja vasta lähempänä rantaa loitosti maalle päin mataloituvaa niin, että saattimella oli vielä muutaman sylen vesi. Liian jyrkkä pohjannousu kohti saatinta aiheuttaa sen, että alipaulat saatinta lähestyessään eivät enää kulje pitkin pohjaa, vaan vedon mukaisesti oikaisevat ylempää, joten haileja pääsee paulan alitse sivulle karkuun; näin koko parvi voi häipyä saattimelta jälleen vapauteen. Sanottu syvyys on "kohtuus talvinuottavesi". Kymmenen sylen vesi on matalamoinen eikä sitä matalammasta vedestä haileja talvella juuri saadakaan; kolmen neljän sylen vedessä ei ole vedetty kuin poilkkeustapauksissa ja silloinkin tavoitellaan lähinnä suomuskalaa. 20-25 sylen vesi on kohtuus syvänlainen ja 25-30 sylen on julman syvä; sitä syvemmälle ei entisaikaan menty.

Pohjan laadun tutkiminen suoritettiin tuuralla, joka kahvastaan sidottiin lapinköyteen. Tuuran annettiin pudota luotaimen tavoin vauhdilla pohjaan. Jos se jäi pystyyn ja vedestä nostettaessa osoitti, että kärjessä oli sinistä savea, niin hyvä oli. Parhain pohja on näet savikenttä, joka yleensä myös on tasainen. Jos savessa oli mukana ruostetta, epäiltiin lähellä olevan kiven; jos savi oli hiekan sekaista, se oli merkkinä, että lähellä mahdollisesti on riutta. Liejuinen on myös sopiva, koska se on tasainen ja koska nuotta on niin painotettu ja rakennettu, että se ei vajoa liejuun. Myös pienemmät pohjasyvänteet, poikkijuovat, jotka eivät muodosta kiintimiä, tekevät luoman huonoksi, kaska pohjan lähellä majaileva kala työntyy niihin ja nuotan alipaula luistaa yli. Siksi pohjan tasaisuus on ensiarvoisen tärkeä; pitkin juopaa kulkeva luoma on myös edullinen.

Varsinaisten kiintimien etsiminen suoritettiin sanotulla köysinuotalla. Jos ala oli tasainen ja siinä puhdas vesi, niin luoma oli yhdellä vedolla tehty. Mutta useammin sattui niin, että "köys on takan", 
jää kiini. Silloin tutkittiin lapinköysiä kiskoen minne päin köydet tekevät, viittaavart, siịs missä suunnassa kiinnin on. Jäätä avaamalla tullaan kiintimen kohdalle, minkä jälkeen tutkitaan kuinka pitkälle pohja on paskanen. Kiintimen paikka ja laajuus ratkaisevat, onko paikasta luovuttava vai voidaanko kiinnin kiertää, jolloin on tehtävä vääjy ja määrättävä tamholttien ja askelmittojen avulla vääjyyn tarkka paikka. Kyllin laajalle tasanteelle saadaan pääluoma ja sen rinnalle jälkiluoma tai luoma voidaan vetää eri kaistoina, jolloin saatin on sama mutta laskimet ovat erikseen.

Perinnäisessä talvinuottaluoman paikan määräämisessä ja sen vedettäväksi avaamisessa on tavattavissa sama täsmällisyys ja etevä kehittyneisyys, mikä on tunnusomaista muullekin tämän tienoon vanhalle yhteisnuottakalastukselle, olipa sitten kysymys kalastuksen teknillisestä suorittamisesta tai nuottakuntien sisäisestä järjestäytymisestä, pyyntivälineistä ja niiden hankinnasta. Ajatellen juuri näitä seutuja, jotka Itämeren piirissä jatkuvasti ovat silakan huomattavimpia kokoontumispaikkoja, vanhan talvinuottakalastuksen keskuksena, on mielenkiintoista panna merkille, miten toinen ikivanha kalastusseutu, Ahvenanmaa, tässäkin suhteessa eroaa Turunmaasta, joka taas puolestaan muodostuu omaksi, suomen- ja ruotsinkielisen kalastajaväestön käsittäväksi kokonaisuudeksi. Esimerkkinä tässä yhteydessä mainittakoon vain pari termiä.

Vanhassa Rymättylän kielenkäytössä osamies on talonisäntä, jolka omistaa osan nuotan peräverkoista - mahdollisesti myös osan reisiverkkoja peräverkkojen suhteessa - ja joka kuuluu siten nuottakunnan pääosakkaisiin; jos hän itse ei ole mukana nuottajäällä, vaan on lähettänyt sijaisen, on tämän edustajan nimi osapoika. Nykyisin heitä nimitetään hevosmiehiksi, mikä johtuu hevosten keskeisestä merkityksestä uudemmassa nuotanvetotavassa. Perä kuuluu nytkin hevosmiesten edustamille taloille. Vastaava nimitys Houtskarissa on lotoman; sen sijaan vastaava vanha nimitys Ahvenanmaalla on ollut *notlage, notlagar, samoin läntisellä Uudellamaalla. ${ }^{15}$ Houtskarista muistiinpantu nimitys lotoman voi olla käännös suomesta, osamies

15 Sven Andersson, *Notlage, notlösare och notgård. Kulturhistoriska axplock tillägnade Gabriel Nikander 21 Maj 1954 (Historiska samfundet i Åbo V), s. $18-19$. 
nimityksellä on näet vastineensa virossa saakka: osamees, ozamēs 'Mitglied' (Wiedemann).

Edellisten vastakohtana entisaikaista nuottaa vetämässä oli suuri joukko enemmän tai vähemmän tilapäisiä henkilöitä, joilla ei ollut osuutta nuotassa. He saivat palkkkansa kaloina, mikäli kalaa tuli. Heistä on käytetty yksinomaan nimeä päiväväki, yksityinen työmies oli päiväläinen, harvemmin päivä-äijä tai päivämies. Turunmaan ruotsinkielisissä pitäjissä tämä apuväki tunnetaan nimellä dagamän (Korppoo, Nauvo, Parainen) tai dagomän (Houtskari, Kemiö); yksinäinen on dagoman, kuten Adolf Moberg 1820 Kemiön Träskön selällä kuulemanaan on nimen kirjannut muistelmiinsa ${ }^{16}$; Petrus Gyllenius käytti nimitystä dagefolcket kuvatessaan 1651 talvikalastusta Korppoossa Norrskatan lähellä. ${ }^{17}$ Ahvenanmaalla vastaava nimitys on vanhastaan ollut kokonaan toinen: notlösare. ${ }^{18}$

Tämäntapaisia esimerkkejä - myös esineellisiä ja sisäistä järjestäy,tymistä koskevia — voisi löytää useampia, mutta niiden etsiminen ei kuulu tämän kirjoitelman piiriin. Rymättylän seudun talvinuottakalastus ansaitsisi oman laajan monografiansa.

\section{KustaA Vilkuna: Finding a Place for Winter Seining at Rymättylä}

Around the Airisto near Turku, seining in winter las been practiced for centuries. The Baltic herring, especially, moves in these waters. Today seining is done around the islands to the west and southwest of the Airisto, i.e. within the limits of the parishes of Rymättylä, Taivassalo, and Iniö.

The seines which are used are about 800 feet long and 80 feet high measured at the seaward edge. They are made by combining nets owned by various farmers. Thus the owners, who are fishermen themselves, form a company, which has from eight to twentyfour (or even more) shareholders. In spring the companies cease operating and they are re-activated each autumn. The practice is that the farms are permanent shareholders in the same companies. Each company has its own name, which is usually a very old one. Names which are still current today are mentioned in a taxation document of 1560. Before the 1870's there were no horse

${ }^{16}$ R. Dahlberg, Professor Adolf Mobergs autobiografi. Svenska Litteratursällskapets Historiska och Litteraturhistoriska studier 3 (1927), s. 111; sama suomeksi: Hyvä taival. Prof. Adolf Mobergin omaelämäkerta vuosilta 18131836, julk. Kirsti Herlin, Hki 1961, s. 17.

${ }^{17}$ Diarium Gyllenianum (julk. Reinh. Hausen 1882), s. 161.

18 Sven Andersson, mt. s. 19-25. 
drawn windlasses; to lift a seine from the water required the work of from 48 to 60 men. Today the same job is done by seven horses and ten or twelve men. The companies are led by the most experienced fisherman. He is called the "king" of the seine.

A part of the king's job is to find a spot under the ice where the bottom of the sea is level enough to allow seining. An area of approximately $800-1300$ yards long and 300 yards wide is necessary. The bottom of the sea arround the islands off Turku is rather uneven; there are rocks and eliffs where a heavy and expensive seine may get stuck and be ruined. Therefore it is important to know exactly where the level areas of the bottom are. This information is the traditional possession of the kings. New seining areas are found by measuring depths and by using a special kind of seine.

Before using a regular seine for the first time in winter, the king has to know the spot where the seine is to be lifted out onto the ice (in Finnish, saatin). From this spot he takes a direction by means of two landmarks, and walks in this direction until he reaches the spot where the seine should be lowered under the ice. This spot is called laskin in Finnish. The laskin is found by using other landmarks: the line determined by two other landmarks intersects the line mentioned above at this spot. A landmark can be a rock, a deep valley, a point of a cape, a larger stone, a tree, a bush, a house etc. These may be miles away. The outlines of the seining area are then determined by plotting the area between the "laskin" and the place where the seine is to be retrieved. The outlines are not always straight lines because there may be rocks at the bottom, which must be avoided. Pictures 1, 2, and 3 show various shapes of areas for winter seining.

Today the fishermen at Rymättylä know about 250 places where seining can be done in winter. Each place has its own name. As it is almost impossible for a man to remember all of the necessary information, the kings have made simple drawings of the landmarks and seining areas (drawing 4). The drawings are like those found in sailing books of the sixteenth and seventeenth centuries.

The oldest written descriptions of places for winter seining date from the year 1842. In that year a very skillful king wrote down in block letters - he could not write cursive seript - descriptions of 62 seining areas. These deseriptins are very skillfully made. Copies of the originals are still in use today. There are many examples of them in the article.

As a whole the organization and practical work of the seining companies is well-established and well organized in every detail. One important activity is defining the exact limits of the winter seining areas. 